\title{
ANALISIS KEMAMPUAN MAHASISWA MENYEDERHANAKAN RANGKAIAN LISTRIK MENGGUNAKAN TEOREMA THEVENIN
}

\author{
Roziana $^{1^{*}}$, Islahudin ${ }^{2}$, Johri Sabaryati ${ }^{3}$ \\ ${ }^{1}$ Mahasiswa Sarjana Program Studi Pendidikan Fisika Universitas Muhammadiyah Mataram \\ ${ }^{283}$ Dosen Progran Studi Pendidikan Fisika Universitas Muhammadiyah Mataram \\ Corresponding author : \\ E-mail : (islahudin.ntb@gmail.com)
}

\section{Diterima 25 Oktober 2017, Disetujui 8 November 2017}

\begin{abstract}
ABSTRAK
Tujuan dalam penelitian ini adalah untuk mengetahui tingkat kemampuan mahasiswa menyederhanakan rangkaian listrik menggunakan Teorema Thevenin di Program Studi Pendidikan Fisika Universitas Muhammadiyah Mataram Tahun Akademik 2016/2017. Jenis penelitian ini adalah penelitian deskriptif kuantitatif. Populasi dalam penelitian ini adalah Mahasiswa Semester I, semester III, semester V dan semester VII yang berjumlah 60 orang mahasiswa Program Studi Pendidikan Fisika Fakultas Keguruan dan IImu Pendidikan Universitas Muhammadiyah Mataram Akademik 2016/2017. Sedangkan sampel dalam penelitian ini adalah mahasiswa semester III (angkatan 2015) dan semester V (angkatan 2014) Program Studi Pendidikan Fisika Fakultas Keguruan dan IImu Pendidikan Universitas Muhammadiyah Mataram Tahun 2017 yang sudah menempuh mata kuliah Elektronika Dasar I. Teknik pengambilan sampel yang digunakan adalah purposive sampling. Analisis data yang digunakan yaitu Distribusi Frekuensi dan Indeks Prestasi Kelompok (IPK). Instrumen yang digunakan dalam penelitian ini ada dua bentuk tes, yaitu bentuk tes soal I menganalisis gambar rangkaian listrik dan menuliskan persamaan $R_{\text {th }}$ yang berjumlah 20 soal dan bentuk tes soal II merubah persamaan hambatan Teorema Thevenin menjadi rangkaian listrik yang terdiri dari 20 soal. Hasil penelitian ini menunjukkan bahwa kemampuan mahasiswa menganalisis gambar rangkaian listrik dan menuliskan persamaan $R_{\text {th }}$ (Instrumen I) Mencapai IPK 47,85 yang tergolong dalam kategori kemampuan sangat rendah, sedangkan IPK semester III (angkatan 2015) mencapai IPK 48,75 yang tergolong dalam kategori sangat rendah dan IPK semester $V$ (angkatan 2014) mencapai IPK 47,03 yang tergolong dalam kategori sangat rendah, sedangkan kemampuan mahasiswa merubah persamaan hambatan Teorema Thevenin menjadi rangkaian listrik (Instrumen II) mencapai IPK 38,2 tergolong kategori sangat rendah, sedangkan IPK semester III (angkatan 2015) mencapai IPK 38,95 yang tergolong dalam kategori sangat rendah dan IPK semester V (angkatan 2014) mencapai IPK 37,5 yang tergolong dalam kategori sangat rendah..
\end{abstract}

Kata kunci : Tingkat kemampuan, Rangkaian listrik, Teorema thevenin

\section{PENDAHULUAN}

Pembelajaran merupakan suatu kegiatan yang melibatkan seseorang dalam upaya memperoleh pengetahuan, keterampilan dan nilai-nilai positif dengan memanfaatkan berbagai sumber untuk belajar. Pembelajaran dapat melibatkan dua pihak yaitu siswa sebagai pembelajar dan guru sebagai fasilitator. Hal yang terpenting dalam kegiatan pembelajaran adalah terjadinya proses belajar. Keberhasilan seseorang dalam belajar ilmu pengetahuan tergantung pada kemampuannya dalam memahami konsep dan teori. Pemahaman tersebut dapat ditunjukkan oleh kemampuannya dalam menerapkan materi yang diajarkan. Pada teorema thevenin, kemampuan yang diterapkan oleh mahasiswa adalah mampu menyederhanakan rangkaian listrik menggunakan teorema thevenin. Menyederhanakan rangkaian listrik menggunakan teorema thevenin dari susunan resistor merupakan suatu kemampuan dasar yang harus dipahami oleh mahasiswa.

Program Studi Pendidikan Fisika. Akan tetapi hal tersebut masih sulit dikuasai oleh sebagian mahasiswa. Sulitnya mahasiswa dalam menyederhanakan dan menuliskan persamaan rangkaian listrik disebabkan juga karena kebiasaan belajar mahasiswa pada program studi pendidikan fisika masih banyak yang menerapkan proses 
belajar hanya pada saat mengikuti perkuliahan saja, belajar masih terpaku hanya pada dosen mata kuliah tentang Elektronika Dasar I, bahkan banyak mahasiswa yang tidak tertarik untuk mencari buku-buku referensi yang berhubungan dengan materi kuliah untuk meningkatkan kemampuan, serta kurangnya keinginan untuk mempelajari kembali materi yang diperoleh dari perkuliahan.

Berdasarkan uraian di atas maka peneliti tertarik melakukan penelitian untuk mengetahui sejauh mana kemampuan mahasiswa Program Studi Pendidikan Fisika Tahun 2017 dalam menyederhanakan rangkaian listrik menggunakan teorema thevenin, sehingga peneliti mengangkat judul penelitian ini yaitu "Analisis Kemampuan Mahasiswa Menyederhanakan Rangkaian Listrik Menggunakan teorema thevenin.

\section{METODE PENELITIAN \\ Jenis Penelitian}

Setiap penelitian memerlukan pendekatan yang menunjukkan cara pengumpulan dan menganalisis data, agar penilaian dapat dilakukan dan dilaksanakan dengan konsisten dan cermat serta serasi dengan tujuan penelitian. Dalam penelitian ini, pendekatan yang digunakan ialah pendekatan penelitian deskriptif kuantitatif yang merupakan cara mengetahui data dengan interprestasi terhadap data yang ditemukan di lapangan (Sugiyono, 2010: 24).

Berdasarkan uraian tersebut, dapat disimpulkan bahwa penelitian deskriptif merupakan penelitian yang mendeskripsikan atau menggambarkan kondisi secara jelas dan apa adanya (alamiah) tanpa adanya perubahan atas keaslian data yang diperoleh.

\section{Populasi dan Sampel}

Menurut Arikunto (2010: 173), populasi adalah keseluruhan subjek penelitian. Apabila seseorang ingin meneliti semua elemen yang ada dalam wilayah penelitian, maka penelitiannya merupakan penelitian populasi.

Menurut sugiyono (2010: 118), sampel adalah bagian dari jumlah dan karakteristik yang dimiliki oleh populasi tersebut.

\section{Instrumen Penelitian}

Arikunto (2010: 203), instrumen penelitian adalah alat atau fasilitas yang digunakan oleh peneliti dalam mengumpulkan data.

\section{Pembuatan Instrumen Penelitian}

Menurut Azwar dalam matondang (2009: 89), menyatakan bahwa tes adalah prosedur yang sistematis, maksudnya (a) butir-butir dalam tes disusun menurut cara dan aturan tertentu, (b) Prosedur administrasi tes dan pemberian angka (scoring) terhadap hasilnya harus jelas dan dispesifikasi secara terperinci, dan (c) setiap orang yang mengambil tes itu harus mendapat butir-butir yang sama dalam kondisi yang sebanding

Instrumen yang dibuat dan disusun dalam penelitian ini terdiri dari dua bentuk tes, yaitu bentuk tes soal I menganalisis gambar rangkaian listrik dan menuliskan persamaan $R_{\text {th. }}$. Bentuk tes soal I terdiri dari 20 soal. Kemudian bentuk tes soal II yaitu merubah persamaan hambatan Teorema Thevenin menjadi rangkaian listrik, dengan jumlah soal sebanyak 20 soal.

Kriteria Pemberian Nilai (skor) Jawaban Adapun beberapa kriteria dalam menilai atau memberi skor hasil jawaban yang diberikan oleh sampel yaitu sebagai berikut:

a. Pemberian skor jawaban berdasarkan metode analisa

b. Skor maksimal jawaban setiap butir soal: 4

c. Skor minimal jawaban setiap butir soal: 1

d. Setiap butir jawaban dibagi menjadi 4 elemen atau step

e. Setiap elemen diberi skor:1

f. Penentuan elemen atau step berdasarkan hasil analisa yang dilakukan oleh pemberi skor pada jawaban yang telah tersedia

g. Untuk instrumen I: menyederhanakan rangkaian listrik hasil jawaban diberi skor 3 yang dipilih menjadi 3 elemen atau step, sedangkan jawaban persamaannya diberi skor 1 yang merupakan satu elemen atau step penilaian dari jawaban

h. Untuk instrumen II: Persamaan rangkaian listrik hasil jawaban diberi skor 3yang dipilih menjadi 3 elemen atau step, sedangkan jawaban gambar diberi skor 1 yang merupakan satu elemen atau step penilaian dari jawaban

\section{Uji Coba Instrumen}

Untuk uji coba instrumen dalam penelitian ini, dilakukan pada mahasiswa program studi pendidikan fisika semester, VII yang telah menempuh mata kuliah Elektronika Dasar I. Setelah instrumen 
diuji coba pada mahasiswa, instrumen tersebut kemudian diuji kelayakannya. Menurut Nurkancana, dkk. (1983: 127), bahwa baik buruknya suatu tes atau suatu alat evaluasi dapat ditinjau dari beberapa segi yaitu validitas, reliabilitas, tingkat kesukaran dan daya beda. Uji kelayakan instrumen dalam penelitian ini meliputi uji: validitas, reliabilitas, daya beda taraf kesukaran dan daya beda.

\section{HASIL DAN PEMBAHASAN Deskripsi Hasil Penelitian}

Penelitian Deskriptif ini telah dilaksanakan dari tanggal 04 Februari 2017 sampai 07 Februari 2017 di Program Studi Pendidikan Fisika Fakultas Keguruan dan IImu Pendidikan Universitas Muhammadiyah Mataram. Populasi yang digunakan dalam penelitian ini adalah mahasiswa fisika Program Studi Pendidikan Fisika Fakultas Keguruan dan Ilmu Pendidikan Universitas Muhammadiyah Mataram tahun akademik 2016/2017. Adapun sampel yang digunakan yaitu mahasiswa fisika semester III (tiga) dan semester V (lima) murni (bukan mahasiswa yang mengulang) yang berjumlah 25 orang mahasiswa. Penelitian ini dilakukan dalam tiga kali pertemuan untuk masing-masing kelas uji coba instrumen satu kali pertemuan yang terdiri dari 18 orang mahasiswa fisika semester VII (angkatan 2013) yang telah menempuh mata kuliah elektronika dasar I dan kelas sampel satu kali pertemuan yang terdiri dari 25 mahasiswa fisika semester III (tiga) murni 12 orang mahasiswa dan semester $\mathrm{V}$ (lima) murni 13 orang mahasiswa bukan mahasiswa yang mengulang.

Data hasil penelitian ini adalah adalah data indeks prestasi kelompok (IPK) mahasiswa fisika semester III (tiga) dan semester $V$ (lima) dengan materi rangkaian listrik pada teori teorema thevenin. Data indeks prestasi kelompok (IPK) ditunjukkan dengan nilai yang diperoleh melalui tes yang diberikan peneliti dengan instrumen pengukuran data berupa tes kognitif yang telah dianalisis melalui uji coba instrumen yaitu validitas, reliabilitas, tingkat kesukaran dan daya beda soal.

\section{Hasil Uji Coba Instrumen Uji Validitas}

Instrumen pengukuran data berupa tes kognitif berbentuk soal uraian yang berjumlah 40 soal uraian yang terdiri dari 20 soal instrumen I dimana mahasiswa diminta menganalisis gambar rangkaian listrik dan menentukan persamaan rangkaian listrik menggunakan teorema thevenin dan 20 soal tes instrumen II dimana mahasiswa diminta untuk menggambarkan rangkaian listrik sederhana. Sebelum tes diberikan kepada mahasiswa, soal-soal tersebut diuji tingkat validitas atau kesahihannya untuk digunakan sebagai instrumen yang layak untuk mengukur Indeks Prestasi Kelompok (IPK) mahasiswa fisika semester III (tiga) dan semester $\mathrm{V}$ (lima). Uji coba instrumen dilakukan pada mahasiswa semester VII (tujuh) yang telah menempuh mata kuliah Elektronika Dasar I dengan jumlah mahasiswa sebanyak 18 orang. Berdasarkan hasil pengujian validitas data tes tersebut dengan menggunakan teknik korelasi product momen untuk jumlah responden $(\mathrm{N})=18$ dan taraf signifikan $5 \%$ dengan $r$ tabel $=0,468$ maka semua soal instrumen I dan instrumen II valid dimana suatu butir soal dikatakan valid jika $r_{x y}>r$ tabel.

\section{Uji Reliabilitas}

Uji coba reliabilitas dimaksudkan untuk menentukan butir soal yang mempunyai taraf kepercayaan yang tinggi uji coba reliabilitas pada 40 soal dengan menggunakan rumus alfa cronbach diperoleh nilai $r$ ( $r$ hitung) sebesar 0.807 pada soal instrumen I dan nilai $r$ ( $r$ hitung) sebesar 0,970 pada soal tes instrumen II. Nilai $r$ tabel untuk $N=18$ dengan taraf signifikan $5 \%$ adalah 0,468.Berdasarkan data hasil uji reliabilitas diperoleh $r$ ( $r$ hitung) lebih besar dari $r$ tabel yaitu pada soal tes instrumen I diperoleh 0,85 >0,468 dan pada soal tes instrumen II diperoleh $1,049>0,468$, maka instrumen pengukuran Indeks Prestasi Kelompok (IPK) berupa tes kognitif yang berjumlah 40 soal dapat dinyatakan memiliki tingkat reliabilitas yang tinggi.

\section{Uji Tingkat Kesukaran Butir Soal}

Uji tingkat kesukaran soal dilakukan untuk mengetahui tingkat kevariasian kesukaran soal yang diberikan kepada mahasiswa. Berdasarkan hasil uji tingkat kesukaran soal, diketahui bahwa pada soal tes instrumen I soal berkriteria sukar sebanyak 2 soal dan pada soal tes instrumen II berkriteria sukar sebanyak 18 soal karena berada pada rentang 0,00 0,30 , soal yang berkriteria sedang pada instrumen I sebanyak 12 soal dan pada soal tes instrumen II sebanyak 2 soal karena berada pada rentang $0,30 \quad-0,70$ dan soal yang berkriteria mudah pada 
instrumen I sebanyak 3soal karena berada pada rentang $0,70-1,00$.

\section{Uji Daya Beda Soal}

Uji daya beda dimaksudkan untuk mengetahui daya beda antar soal sehingga menjadi instrumen pengukuran yang baik. Berdasarkan hasil uji coba daya beda soal,maka dapat disimpulkan bahwa sol yang memiliki daya beda jelek pada soal tes instrumen I sebanyak 10 soal dan pada soal tes instrumen II sebanyak 17 soal karena berada pada rentang $0,00<$ 0,20 , soal yang memiliki daya beda cukup pada soal tes instrumen I sebanyak 5 soal dan pada soal tes instrumen II sebanyak 3 soal karena berada pada rentang 0,20< 0,40 dan soal yang memiliki daya beda baik pada soal tes instrumen I sebanyak 5 soal dan pada soal tes instrumen II tidak ada soal yang baik karena berada pada rentang $0,40<0,70$.

\section{Pembahasan}

Analisis kemampuan mahasiswa menyederhanakan rangkaian listrik menggunakan teorema thevenin merupakan sebuah kemampuan yang dimiliki seseorang untuk melakukan analisis suatu permasalahan yang didasarkan pada kemampuan seseorang merupakan tindakan untuk mengkaji, menguraikan dan menelaah kemampuan sebenarnya seseorang atau individu dalam mengerti atau memahami sesuatu. Analisis kemampuan menggambar dan menuliskan persamaan rangkaian listrik dapat diterapkan pada materi rangkaian listrik dan teorema thevenin.

Data hasil penelitian analisis kemampuan menyederhanakan rangkaian listrik menggunakan teorema thevenin yang dianalisis untuk membentuk persamaan rangkaian listrik menggunakan teorema thevenin yang diujikan pada sampel dengan jumlah sampel 25 orang mahasiswa semester III (tiga) dan semester V (lima) pada Program Studi Pendidikan Fisika. Skor rata-rata (M) yang diperoleh 38,28 dengan standar deviasi (SD) sebesar 7,30. Sedangkan skor maksimal yang diperoleh sebesar 60 dan skor minimal sebesar 20. Sehingga diperoleh jumlah interval 5,61 dibulatkan menjadi 6 dan lebar interval 6,66 dibulatkan menjadi 7.Selanjutnya data statistik yang telah diperoleh dianalisis mengunakan distribusi frekuensi terurai pada Tabel 4.4 dan dari hasil perhitungan data, diperoleh Indeks Prestasi Kelompok (IPK) kemampuan 25 mahasiswa menganalisis gambar rangkaian listrik untuk diubah menjadi persamaan rangkaian listrik menggunakan teorema thevenin adalah sebesar 47,85 yang berada pada kategori tingkat kemampuan sangat rendah. Hal ini menunjukkan bahwa mahasiswa tidak mampu menyelesaikan permasalahan pada soal gambar rangkaian listrik yang dianalisis menjadi persamaan rangkaian listrik menggunakan teorema thevenin. Karena mahasiswa jarang latihan, jarang diskusi dan jarang membaca buku sehingga kemampuan mahasiswa rendah.

Data hasil penelitian analisis kemampuan menuliskan persamaan rangkaian listrik menggunakan teorema thevenin yang dianalisis untuk membuat rangkaian listrik menggunakan teorema thevenin yang diujikan pada sampel dengan jumlah sampel 25 orang mahasiswa semester III (tiga) dan semester $V$ (lima) pada Program Studi Pendidikan Fisika. Skor rata-rata (M) yang diperoleh 38,25 dengan standar deviasi (SD) sebesar 40,84. Sedangkan skor maksimal yang diperoleh sebesar 44 dan skor minimal sebesar 20. Sehingga diperoleh jumlah interval 5,61 dan lebar interval 4. Selanjutnya data statistik yang telah di peroleh di analisis mengunakan distribusi frekuensi terurai pada Tabel 4.8 dan dari hasil perhitungan data, diperoleh Indeks Prestasi Kelompok (IPK) kemampuan 25 mahasiswa menganalisis persamaan rangkaian listrik untuk diubah menjadi gambar rangkaian listrik menggunakan teorema thevenin adalah sebesar 38,2 yang berada pada kategori tingkat kemampuan sangat rendah. Hal ini menunjukkan bahwa mahasiswa tidak mampu menyelesaikan permasalahan pada soal gambar rangkaian listrik yang dianalisis menjadi persamaan rangkaian listrik menggunakan teorema thevenin. Karena mahasiswa jarang latihan, jarang diskusi dan jarang membaca buku sehingga kemampuan mahasiswa rendah.

\section{KESIMPULAN}

Berdasarkan hasil penelitian yang telah dilakukan maka dapat disimpulkan bahwa kemampuan mahasiswa menganalisis gambar dan menuliskan persamaan rangkaian listrik dengan menggunakan teorema thevenin di Program Studi Pendidikan Fisika Fakultas Keguruan dan IImu Pendidikan Uniersitas Muhammadiyah Mataram. Pada Instrumen I jika diuraikan berdasarkan semester III (tiga) dan semester V(lima) makamemiliki IPK semester III (angkatan 2014) diperoleh 
IPK 48,75 dan IPK semester $\mathrm{V}$ (angkatan 2015) tergolong kategori sangat rendah. Sedangkan kemampuan mahasiswa merubah persamaan hambataan menggunakan teorema thevenin menjadi rangkaian listrik di Program Studi Pendidikan Fisika Fakultas Keguruan dan Ilmu Pendidikan Universitas Muhammadiyah Mataram. Pada instrumen II, jika diuraikan berdasarkan semester III (angkatan 2014)memiliki IPK 38, 25 dan IPK semester V (angkatan 2015) tergolong kategori sangat rendah.

\section{UCAPAN TERIMA KASIH}

Terimakasih buat siswa yang sudah mau yang dijadikan sampel uji coba dalam penelitian ini dan orang-orang yang membantu memberikan dukungan baik secara moril maupun materiil.

\section{DAFTAR PUSTAKA}

Arikunto, Suharsimi. 2010. Prosedur Penelitian Suatu Pendekatan Praktik. Jakarta: Rineka Cipta.

Barorah, St. Nurlaelan. 2014. Analisis Kemampuan Berlogika Mahasiswa Tentang Konsep Gerak Relative Pada Teori Relativitas Khusus Di Program Studi Pendidikan Fisika Universitas Muhammadiyah Mataram Tahun Akademik 2013/2014 (Skripsi). Mataram: Universitas Muhamadiyah Mataram.

Erfy Pratiwi, dkk. 2015: desain masalah pada topik rangkaian listrik untuk metode pembelajaran berbasis masalah. Jurnal, radiasi volume 06 No. 1 April 2015

Hindayati Mustafidah, 2009: Pengembangan Perangkat Lunak Komputer Untuk Mengevaluasi Soal Tes. Jurnal, Jilid 12, No 1, Februari 2009. Banyumas: Universitas Muhammadiyah Purwokerto.

Matondang Zulkifli, 2009: Validitas dan Reliabiltas Suatu Instrumen Penelitian. Jurnal Tabularasa PPS Unimed, Vol.6 No.1, Juni 2009. Medan: Universitas Negeri Medan.

Mussakib, Annaz. 2014. Analisis Pemahaman Mahasiswa Tentang Konsep Gerbang Logika Menggunakan Aljabar Boole Di Program Studi Pendidikan Fisika Universitas Muhammadiyah
Volume 3, Nomor 2, November 2017 p-ISSN : 2460-9587 e-ISSN : 2614-7017

Mataram Tahun Akademik 2013/2014(Skripsi). Mataram: Universitas Muhammadiyah Mataram

Nurkancana, dkk. 1990. Evaluasi Hasil Belajar. Surabaya: Usaha Nasional.

Nusaku, Legendaria. Okta. Bellany, dkk. 2014. Analisis Kemampuan Dan Kompetensi Terhadap Kinerja Pegawai. Jurnal Sains Manajemen, Vol 3, No 1, April 2014. Kota Waringin Timur: UNPAR.

Sugiyono. 2010. Metode Penelitian Pendidikan Pendekatan Kuantitatif Kualitatif dan R\&D. Bandung: Alfabeta.

Sutrisno. 1987. Elektronika Dasar I. Bandung: Penerbit ITB.

Tim Dosen Elektronika Dasar I. 2013.Panduan Praktikum Elektronika Dasar I. Program Studi Pendidikan Fisika: Fakultas Keguruan Dan IImu Pendidikan Uiversitas Muhammadiyah Mataram.

Tim Pustaka Phoenix. 2012. Kamus Bahasa Indonesia Edisi Baru. Jakarta: PT Media Pustaka Phoenix. 